\title{
SUCCESS FACTORS FOR UNIVERSITY INCUBATORS - A BENCHMARKING MODEL FOR BETTER PERFORMANCE
}

\begin{abstract}
Changing economic circumstances and technological advances are having an impact on the economic and social role of universities. Nowadays, university students, teachers and researchers are coming up with more and more innovative ideas, but they are unable to put their results into practice because of their lack of entrepreneurial skills. University incubators are specialised business incubators that create a link between university, business, and government, generating a significant impact on the local economy. In our research, we have highlighted the aspects that may be most relevant to the operation of 48 incubators in the world and analysed their performance. The comparative analysis allowed the creation of a standard model and the presentation of its success factors.
\end{abstract}

KEYWORDS: university incubators, triple helix, competitiveness

\section{INTRODUCTION}

Rapidly changing economic conditions and technological developments are affecting businesses, both in terms of their numbers and their growth potential. The same is true for the economic and social role of universities. Thanks to this rapid development, university students, teachers and researchers are coming up with more and more innovative ideas, but they are afraid/unable to transfer this knowledge and put it into practice because of their lack of entrepreneurial skills; or if they do start their businesses, they may fail early because of their lack of such skills. University incubators have been created to stimulate entrepreneurship, to help overcome initial difficulties and to enhance the role of universities in the economy. A university incubator is a special type of business incubator that links the higher education institution, the local business community, and the state, and can therefore have a significant impact on economic development. As well as providing specific services, it is equally important to develop and transfer entrepreneurial skills; to promote entrepreneurial thinking and culture, and to support leadership and institutional development. An attempt has also been made to typify university incubators in all possible ways, reflecting their diversity and different functions. 


\section{ENTERPRISE DEVELOPMENT AND INCUBATION}

2.1 Enterprises, enterprise development

The number and role of small and medium-sized enterprises (SMEs) in countries are outstanding, they underpin the economic stability and growth of a country, play an important role in GDP generation and are a driving force for job creation. But who is an entrepreneur and what do we call an enterprise? There are many definitions to explain these terms. The word 'entrepreneur' comes from the French word 'entreprendre', which means to undertake, to try and take risks.

Some emphasize the mediating character of the entrepreneur [Drucker, 1993], [Cantillon, 1755], [Szirmai, 2005], others emphasize his organizing and guiding function [Daniel, 201G], [Spinelli, S \& Timmons, J. A., 2003], or emphasize the entrepreneurial process [Hisrich \& Peters, 1991], [Vecsenyi, 2009], but many researchers also see innovation as an important element, [Schumpeter, 1980a] [Schumpeter, 1980b], [Szerb, 2004], [Fülöp, 2004], [Filion, 2011].

Improving competitiveness, efficiency and productivity are the main objectives of enterprise development. There are two broad categories of development instruments: financial and non-financial instruments (also known as business development services). Financial elements include loan programmes, capital programmes and tenders; non-financial elements include education, training, consultancy and management services. Interventions can be (1) macro-level interventions aimed at improving the overall business environment (tax and administrative burdens on enterprises); (2) meso-level interventions targeting service providers (start-up of incubators, service development); and (3) micro-level interventions aimed at directly supporting enterprises (financing asset acquisition, development).

The services provided by the European Union to SMEs are categorised as follows: provision of basic information, professional information services: market, financial and business information, provision of premises and environment, financing, advice and direct support, training, actions.

According to OECD and UNIDO ${ }^{1}$, the most important groups of interventions are advisory services, financial programmes, and business incubation [Imreh, 2005].

Business incubation emerged in Europe in the 1970s and 1980s and, from the 1990s onwards, increasingly specialised forms of incubators emerged: technology, "open-walled" and industry-specific incubators. During the late 1990s, the emergence of the new economy and virtual incubators to support ICT start-ups has started. This took the development of incubation to a new level, with the 
primary objective of raising capital. [Bajmócy, 2004a] [Buzás, et al., 2003]. In the European Union, too, the development and support of SMEs have become increasingly important for job creation and innovation. Outsourcing has played an important role in this. It has highlighted the need for links between SMEs and transnational companies, thus 'connecting' the global economy with the local one. [Bajmócy, 2011].

\subsection{Incubation, types of incubators}

Business incubation is a means of supporting start-ups and helping them to develop through various services, which can be defined in several ways. In a narrow sense, it is defined as institutions that provide start-ups with a space to operate and services. Spatial proximity can create various synergies. In a broader sense, this includes industrial parks, technology centres and regional clusters, which have at their core the provision of a specialised environment [Bajmócy, 2004a]. The European Union's research has coined the concept of a consensus business incubator: "An organisation that accelerates and systematises the process of creating successful businesses by providing them with comprehensive and integrated services, including incubation space, supportive business services, clustering and networking." [European Commission, 2002]

Incubators can aim to select start-ups with the potential to grow and help them to develop [Wanklin, 2002]. They can be typified according to the different services they provide [Carayannis and Zedtwitz, 2005] or according to their objectives and funding [Grimaldi and Grandi 2005]. Non-profit incubators are usually university incubators [Lewis, 2001] [Bajmócy, 2004a]. It is important what type of enterprises would be supported, for example, small business development, which includes both traditional and technological incubation, a broad range of development tools regardless of the stage of development of the enterprises, start-up development, in which case almost all start-ups can be supported, regardless of the industry or innovative activity, and innovative enterprise development, in which case innovative small enterprises are supported, where there is a high potential for growth [Malizia, et al., 1997] [Bajmócy, 2004b].

\subsection{Incubation process, services provided}

Small and medium-sized enterprises, due to their size, organisational structure, and smaller market size, have more difficulties in overcoming the difficulties they face in their start-up and development. The incubation process is an opportunity for firms to overcome such obstacles. The development of the supported firms can be divided into three phases. An entry screening process (1) selects companies that have the potential to grow. At the level of resource provision (2), we can find all the resources that incubators can provide to achieve success, and finally, we can 
talk about the intensity of service provision and monitoring (3), i.e., the efficiency and level at which incubators can provide services [Hackett \& Dilts, 2004] [Bajmócy, 2011]. Incubator services can be classified into three basic groups: administrative, operational and strategic services. Administrative services provide basic services focused on a single industry, often with low value-added, which most incubators can provide. Operational services are similar to the former but are now complemented by other office services. Strategic services are a much more detailed set of services. This includes consultancy, training, management, research and development, innovation, technology transfer, etc. [Kaszás et al, 201G]. They can provide not only operational space but also specific technological services (equipment, laboratories, training) that the private sector would not be able to provide, in most cases addressing a real market failure [Bajmócy, 2004a].

\subsection{Factors affecting the success of incubation}

Four groups of factors can be highlighted the success of incubators. Firstly, the entrepreneurial environment, which is a key factor in the life of an incubator, including the local economic environment, infrastructure, entrepreneurship (successful entrepreneurial patterns and their social recognition), and the propensity to innovate. At the second we can talk about the technological environment, i.e., knowledge creation, technical/technological development is also prominent, the creation of scientific and technological background in the regions contributes greatly to the development of start-ups and to improve their competitiveness. Factors such as innovative companies cooperating with universities and research institutes, tenders to support R\&D activities of enterprises, networking of enterprises [Birkner et al, 2012]. The third factor is business support, which helps to transfer new knowledge and to succeed in the knowledge-based competition through various forms of cooperation, such as incubators, business networks, industry associations (transfer of know-how and experience). Finally, fourthly, financial resources are a factor, as businesses may have problems in raising the necessary capital due to a lack of information or financial expertise. These groups of factors are partly the same as the usual factors of production: entrepreneurship - business environment, labour - business support, capital - financial resources, technology rather than natural resources [Malecki, 1997] [Lengyel, 2002]. In his study, Bajmócy concludes that there are a limited number of regions in Hungary where business incubators supporting technology-oriented entrepreneurship would be successful. Such areas could be Budapest, the capital; larger regional centres, educational centres [Bajmócy, 2004b]. 


\section{THE ROLE OF UNIVERSITIES IN THE ECONOMY AND ECONOMIC DEVELOPMENT}

The objectives of universities are becoming increasingly broader as they develop, with a generational distinction being made during their development. The almost exclusive purpose of first-generation universities is education. Secondgeneration universities also have research as an objective, operate on the local market and are mainly characterised by elite training. Third-generation universities, in their teaching and research, seek to adapt as far as possible to the changing economic and social environment, to build up links with partners outside the university and exploit the know-how generated. Not only elite education is present, but also mass education and training take place, as well as international competition. The boundaries between generations are not sharply separated [Wissema, 2009]. Pawlowski also mentions the fourth generation of universities, whose purpose is complemented by a focus on the needs of the knowledge economy and, consequently, an attempt to influence its environment [Pawlowski, 2009].

As the objectives of higher education institutions have expanded, their economic involvement, their role in the economy and their impact on it have become increasingly important. These impacts can be divided into two parts (input-output side): one is essentially the impact of the university's presence; the other is the impact of its operation and scope of activities. The result of the educational function is the skilled workforce potentially exported to the local economy, the research function results in the creation and exploitation of new knowledge and may also play a role in the development of a specific local community [Bajmócy, 2011].

The presence of these knowledge-concentrating institutions is decisive in terms of their economic influence in the regions, but this is not sufficient to achieve success. The development of university-industry links contributes significantly to the transfer of knowledge and the exploitation of results generated in universities. For this to happen, the public sector has a role to play alongside universities and the private sector. The model of university-industry-government cooperation is called the Triple Helix. The common goal of the three entities is to increase innovation, competitiveness, and economic development [Feketéné Czakó, 2017]. This cooperation is important from the perspective of the three sectors because it can provide a competitive advantage to the private sector; the state helps the economic exploitation of the results of university education and research, which contributes to economic growth and can compensate for the scarce/decreasing subsidies to the institution; and universities turn to economic actors because of the limits of their own resources [Bajmócy, 2005]. 
The role of universities has started to change, which the literature calls "entrepreneurial universities". Etzkowitz et al [2000] break down the emergence of this into three operations. They point out that knowledge as a resource began to become more important than traditional factors of production (1), thus making the role of universities increasingly dominant in innovation systems, and that the public, private and academic spheres created an interconnected network system in which all actors were equal [Etzkowitz, et al., 2000]. The emergence of university incubators has been driven not only by the growing economic involvement of higher education institutions, but also by their organisational interests (2). Rivalries between universities for students, researchers and research resources are taking place. They strive to perform as well as possible in the competitive arena, while at the same time building a good reputation. In addition, they can earn substantial revenues if they are not closed to capital investment (3) [Buzás, 2003].

The economic role of universities is linked to their entrepreneurial activities. As Goldstein [2010] points it, "(1) the active participation of the university as an institution in the development and commercialisation of technology arising from university research; and (2) internal regulation, remuneration and incentives, behavioural norms, and changes in university governance to remove barriers to the activities of individual faculties, researchers and research centres/institutes that lead to the commercialisation of knowledge created at the university."

In Europe, as in the US, efforts have been made to commercialise university inventions. However, the US success stories cannot be considered as a complete model, as there may be institutional differences that may lead to the introduction of similar regulations. The creation of businesses linked to university research can contribute to the exploitation of knowledge and networking in the economy. Technology transfer offices, science parks and incubators (services, support) will help to make this happen [Erdős, 2019].

The most important issue for university incubation is the direct use of knowledge in the economy, which is linked to the creation of spin-offs. During spin-off formation, founders face challenges that are not separated in time [Clarysse, et al., 2005]. To overcome these challenges, a start-up may not yet have the necessary network of contacts and knowledge. Furthermore, in many cases, the researcher is not motivated to put his or her idea to use in business and does not want to be involved. Consequently, only a small proportion of ideas become technology-oriented small businesses. The incubators aim to help with this initial difficulty and to contribute to their rapid growth in the future. University incubation is preceded by pre-incubation, whose main task is to motivate and encourage researchers to put their ideas into practice [Bajmócy, 200G].

There are many definitions of university spin-off companies in the literature, but the fact that they are profit-oriented companies can be found in all of them 
[Makra, 2013]. Spin-off companies are characterised by the participation of a university/other national research institution with an equity stake [Kleinheincz, 2002]. Spin-off companies are new firms created to exploit knowledge, technology or research results developed within the university [Pirnay, et al., 2003].

In the words of Gazdig [2009], spin-off firms are: "innovative small enterprises set up by employees of a university or a public research centre to commercialise their own research results. Their creation, however, not only benefits the researcher who becomes an entrepreneur, but also the parent institution, which can gain additional resources through spin-offs."

\subsection{University incubators}

The National Business Incubation Association defines incubation as a mechanism that supports entrepreneurs by providing resources and services to help them create new businesses. Incubators help new entrepreneurs in a variety of ways. Al-mubaraki and Busler [2010] describe the services and functions of incubators, such as shared space with technical equipment, managerial support,

networking, access to knowledge and financial capital, and encouraging entrepreneurs through start-up funding support. However, university incubators are entities that are adopted by states to foster an ecosystem by supporting spinoffs and small and medium enterprises in the development and growth phase [Studdard, 200G]. In another study, Somsuk, Laosirihongthong and McLean [2012] grouped the resources needed to support entrepreneurs in university incubators

into four main categories, such as human, financial, organizational, and technological resources. Likewise, Salem [2014] identified university incubators as the most influential type of incubator, and according to him, student entrepreneurs take advantage of university incubators to connect with industry to create their own businesses. Several dimensions appear to be success factors in university incubators, such as infrastructure, networking, human and technical support, faculty and staff, and institutional reputation [Grimaldi \& Grandi, 2005].

Many incubators in the world are founded and run by universities. Other incubators are also looking to collaborate with universities and higher education institutions to achieve the benefits of synergies between their research and knowledge. Innovation, commerce, and entrepreneurship in society contribute significantly to economic development through incubators. Incubators have been recognised as a promotional tool for economic recovery, job creation, for the creation of new entrepreneurs, for enhancement of entrepreneurial performance and commercialisation in both developed and developing countries [Tamásy, 2007]. Similarly, university incubators are analysed as a means of promoting trade through the creation of spin-offs. Somsuk et al. [2012] describe incubators as a mechanism for promoting entrepreneurial culture to create spin-offs and increase 
survival rates. Chandra et al. [2012] explained that university-supported incubators have adequate background in human expertise, funding source, location, innovation, and trade development, while the participation of industrial incubators is lacking. The role of university incubators, however, is not limited to providing services to start-ups, but rather to fulfil a facilitative attitude towards leadership and institutional development by supporting entrepreneurial thinking and culture [Audretsch, 2014].

\subsection{Possible typology of university incubators}

Clarysse and colleagues [2005] were among the first to attempt to typify university incubators. They considered three main aspects: the incubators' scope of activities, what resources they use and their reference model. Todorovic and Suntornpithug [2008] focused on the unique role of universities and the network of contacts/communities that universities have developed. They also paid attention to different skills, entrepreneurial culture, and resource use. Barbero et al [2014] identified different archetypes of incubators concerning innovation as a key factor, including economic development, basic research, university ventures, and corporate research and development. Wonglimpiyarat [201G] considered four aspects in typifying incubators: the budgetary resources required, whether funded by the university or the state, the maturity stage of the ventures, what area they focus on, and their operational functions.

Nicholls et al [2020] have examined how existing studies have attempted to typify university incubators. They then used these to define their own, more detailed typologies. The main aspects they considered were stakeholders, objectives, strategic focus, incubation process, resources and services, and socioeconomic impacts, and within these, they identified other sub-dimensions.

The typology proposed by Nicholls et al [2020] is more detailed than the previous ones. Their proposed typology allows researchers to capture types of university incubators while comparing their characteristics systematically along with a common set of dimensions. It reveals the heterogeneity of university incubators along the lines of key stakeholders, dominant institutional logic, objectives, strategic focus, incubation process, resources and services provided, and their socio-economic impact [Wann, et al., 2017].

The university incubator's strategy reflects its objectives and the chosen business model. Within the objectives, different strategic choices are possible for different university incubators, including sector focus, life cycle stage and desired impact over time as well as space. These strategic choices are driven by the design of a business model, including the choice of revenue streams (rents, fees, royalties/equity, or sponsor support] and the choice of cost structure [Dee, et al., 2011]. The choice of strategic focus also defines the control structure, such as the management of the university incubator or the degree of proactive intervention 
that the university incubator management implements in the incubated new ventures [Lewis, et al., 2011].

For university incubators, a key decision is how to obtain resources for the strategic focus chosen and how to transform them into services. They can decide to copy the same incubators or choose those that are specifically needed for new businesses. Unfortunately, there is no survey to rigorously determine what is needed. Therefore, many choose the typical offerings: infrastructure, training, networking, and capital [Hausberg \& Korreck, 2018].

Recent research suggests that less objective resources and services such as culture, legitimacy, and social capital play an important role [Redondo \& Camarero, 2018]. Culture offers new ventures through community support, identity and negotiating boundaries with stakeholders and other institutional or market actors [Theodorakopoulos, et al., 2014].

The impact of a university incubator on its stakeholders can be quite varied, with generally positive effects. For the university, these may include developing entrepreneurial skills, stimulating entrepreneurship on campus, or stimulating innovation. The commercialisation of university intellectual property can lead to regional economic development and increased employment [Jamil, et al., 2015] [Lasrado, et al., 201G]. And some benefit all future businesses that involve the same individuals (i.e., acting as serial producers) [Westhead, et al., 2005].

\section{RESEARCH MATERIAL AND METHODS USED}

Following the literature review, we asked ourselves the research question: could a set of criteria be developed that would allow for some form of standardised typology of university incubators around the world? Accordingly, the main objective of our research was to translate the typologies found in the literature into a common set of criteria, supplemented by the elements that we had found in our own experience of studying incubators. A further objective is to identify the characteristics that most characterise incubators and those that least. Finally, our aim is to show which incubators are closest to the "standard", i.e., which have the most general characteristics, and which are furthest from it.

The research topic of our study is relevant to the application of secondary research. The growing role of businesses and universities, the creation of incubators linked to or based at universities, their role in the economy and their economic impact have been studied by different researchers before. Our study focuses on these factors, the services and training they provide. As mentioned above, one of the tools for business development is the creation of business incubators, one of the most well-known types of business incubators today being university incubators. Incubators can help start-ups in a few ways. They can 
support them not only by providing space but also by providing them with networking and financial capital, mentoring and ongoing advice to help them develop. The university environment is more specialised than traditional incubators. On the one hand, universities are active players in R\&D\&I, in encouraging business start-ups, and on the other hand, they can facilitate contacts with experts and other business leaders. By reviewing the literature on the subject, the incubators examined were identified using the following keywords: university incubator, university business incubation, university incubator ranking, entrepreneurship centres, university support for entrepreneurship, start-ups, etc. Finally, incubators set up by universities on all continents were identified; 48 university incubators were examined and compared based on a specific set of criteria. By reviewing the typological characteristics of university incubators identified by other researchers, we highlighted the aspects we considered more important and assigned characteristics to each aspect, thus creating another possible typology of university incubators.

Table 1: Assessment criteria

Criteria

Stakeholders

Primary objective

Expected outputs

Strategic focus

Intervention

Leadership

Value creation

Infrastructure

Training

Services provided

Origin of capital

Organisational culture
Characteristics

University, foundations, investors, government

Profit-oriented, education-oriented, economic development-oriented, social developmentoriented

Efficiency, effectiveness, utilisation, efficiency

Sectors, time horizon, social, geographical, and political groups

Quantitative, quantitative

Autonomous, stakeholder involvement

Developments, customization

Spatiality, instruments

Mentoring, training, consultations, specific knowledge

Buyers, investors, marketing, PR, tendering

Own resources, partner funds

Power type, role type, task type, person typ

Source: own editing 
Probably one of the most prominent aspects is who the stakeholders of the incubators are. Universities should be mentioned, of course, as they are (one of) the founders of the incubator, and students, teachers and researchers from the university can be active members. Also interested in government economic development, foundations, investors from a funding service point of view. The importance of stakeholders in university incubators was also cited by Lasrado and his co-authors as one of the most important [Lasrado, et al., 201G].

The objectives of each incubator may also differ from each other, it is worth observing these in each case. Stal and colleagues also looked at the goals of the incubators they studied separately [Stal, et al., 201G]. The presence of universities is becoming increasingly important and their role in the economy is growing, so they can make a significant contribution to economic development. From another perspective, looking at their objectives, what outputs are expected from their participating enterprises. By effectiveness and efficiency, we mean that enterprises deliver the desired results, achieve the objectives they set, and do so in the best possible way. They are effective, i.e., they have a significant impact and use the services provided to the best of their ability.

University incubators have different options for choosing their strategy. They can focus on specific sectors, on businesses at different stages of their life cycle, and those found within a particular region (geography) or created by a particular socio-political group [Dahms \& Kingkaew, 201G].

Incubators may be run by universities on their own or maybe a collaboration between several higher education institutions or may involve stakeholders outside universities, for example with contributions from government or individual investors. The extent to which individual partners control the organisation can be decisive [Schillaci, et al., 2011]. They may implement a variety of value-adding interventions, often tailored to different stages of development, but these interventions may vary according to the needs of the business to adapt to change and to the best possible development of different firms [Roseira, et al., 2014]. In terms of infrastructure, one of the most important may be whether the incubator provides operational space for businesses and access to any facilities. This may change as needs evolve [Ermakov, 201G]. University incubators place a strong emphasis on developing entrepreneurial skills, so they also focus on this in their various training activities, through education and specific skills. In addition, they provide opportunities to consult with experts and academics, and in some institutions, entrepreneurs can also be mentored. Among the services provided, we highlight public relations activities, contacts with customers and investors, the development of an appropriate marketing strategy and assistance with tenders.

To start a business, companies need to have sufficient capital, but this can be a barrier. If their own resources are not sufficient, they can make their plans a reality 
by partnering with university incubator networks [Jamil, et al., 2015]. We considered an important aspect of investigation for these institutions to be what characterizes their organizational culture, for this purpose we drew on Charles Handy's [198G] cultural typology.

\section{ANALYSIS OF THE INCUBATORS IN THE SAMPLE}

There are a significant number of university-affiliated incubators established in universities around the world. Our research confirms that they are found on all continents, in the Americas, Europe, Asia, Australia and even Africa. Their importance to the economy is recognised almost everywhere. The 48 university incubators and incubator services found (selected) by desktop research and analysed later according to the criteria mentioned above have a significant impact on the region and play a key role. Of the incubators found, 20 are in the Americas, 14 in Europe, G in Asia, 4 in Australia and 4 in Africa.

Analysing the characteristics of the incubators found, we conclude that, on average, they have helped 144 businesses get off the ground so far. The incubator at the University of Chicago has the highest number of incubated businesses, with G50 successfully incubated, followed by Northwestern University with 550, and Ryerson University in Canada in third place. As the North American continent is considered the cradle of incubators, the result is in line with expectations. Incubators have been operating for an average of 12 years, with 3 of them more than 20 years old.

We also looked at how specialised each incubator is, in line with the literature. Of the 48 organisations surveyed, only six could claim to support businesses in a specific field, the others had no such limitation. The specialisations were typically in the fields of energy, food, health. The Sharda University incubator in India, for example, has been successful in the field of microelectronics, where joint development has resulted in 10 patents for the 18 incubated companies. Specialisation (or lack of it) has coincided with the activities of universities. The broader the portfolio of university courses, the less specialised the incubator.

Finally, we sought to investigate how many of the incubator operators we found could be considered third-generation universities. No first generation was found, as all the organisations studied had specialised training and services based on local needs. As in Wissema's [2009] study, we found a fine line between second and third-generation universities, with the majority of these two categories, twothirds of the organisations studied. A total of 10 were identified as fourthgeneration institutions in the study, typically located in North America (G), Australia (2), the UK, and India (1-1). We could therefore conclude that the incubators studied were typical of the typology found in previous studies [Wissema, 2009] and [Pawlowski, 2009]. 
We have analysed the selected university incubators according to our criteria. For each incubator, we looked at how many and which characteristics were found within each aspect, which of these were found in most of them, and from this data we identified which factors were most important for them to be successful.

The first aspect we looked at is who and how many stakeholders are involved in the operation of the incubators. The analysis showed that for most incubators (21 here) there are typically 3 stakeholders, with the university, students and businesses being identified in most cases. For 12 incubators, 4 stakeholders were found, with academics and researchers being more involved than before, and in 10 cases only 2 parties were involved.

The second aspect that was examined was the key objectives that they have. Economic development, social development, educational orientation, and profit orientation were highlighted. Overall, a university incubator typically has two objectives in mind, in this case, we found this to be the case for 24. UCF (University of Central Florida) also highlighted in their Business Incubation Program that their goal is to stimulate economic growth throughout the region by creating and sustaining jobs in the community. For the remainder, we found a predominance (22) with one goal and a minority (2) with three goals.

They also focus on the outputs that will be achieved using services provided to incubated businesses. For this aspect, we studied effectiveness, efficiency, effectiveness, and utilisation. Thus, in summary, like the primary objectives, incubators expecting two outputs were the most numerous (22), one output was found in $1 \mathrm{G}$ and three or more in 10. The FMU incubator (Francis Marion University) also has two main requirements for businesses, to report monthly on their progress towards their goals, i.e., how effective, and efficient they have been over the period.

Strategically, they may focus on a specific sector, a particular social group, or a geopolitical group. There are higher education institutions that only support businesses in a particular sector, such as Cranfield University in the UK, which supports aeronautical engineers, or Kyambogo University (Uganda), which aims to boost research and innovation in bakery and confectionery, or Rosalind Franklin University in the US, which supports researchers in the biological sciences.

But some support only a specific social group, by which we mean only businesses set up by students, alumni or academics who are in higher education or have been involved in higher education. In many cases these aspects are not separate, so we can also talk about mixed strategies. Of the 48 universities, 19 were found to focus only on a specific sector, the same number to be mixed, and 10 to offer their services only to a specific segment of society.

When university incubators are set up, they also specify the amount and extent of intervention they are willing to make in the operation of the businesses. 
Quantitative intervention means that they try to support them by providing more services; quantitative intervention means that they can benefit from discounts on certain services. In the study, there were $2 \mathrm{G}$ incubators where we found only quantitative intervention, 20 where we found a mixture of both, and only 2 where we found only quantitative intervention.

In terms of leadership, we found that in 32 out of 48, leadership is provided by universities alone. In some cases, however, we found the involvement of some other stakeholder, such as the government or an investor. In total, there were 11 cases of management with only the involvement of a stakeholder, and 5 cases of 'two' together. The IPN Incubator in Portugal was established by the University of Coimbra and the Pedro Nunes Institute and is therefore managed jointly.

The value-adding processes for companies in the incubation process can vary. This includes activities related to different development activities as well as activities related to the customisation of the business. As different companies may join incubators at different stages of maturity, different interventions are needed. Therefore, we found that 29 universities put more emphasis on development, the BME Z10 incubator in Hungary was the one where the most interventions were tailored to specific needs, and 18 where the two were combined, i.e., developmenttargeting.

It was mentioned that the lack of assessment of the resources needed for new businesses makes university incubators the typical offer (like other incubators). For example, equipment that is available in university laboratories, but which is not worth the investment for a company to have access to at a discount. In 39 cases, university incubators offer both services, to help companies through the initial difficulties. In G cases, they were found to provide only operational space and in 3 cases, they provided access to certain tools at a discount.

Training activities are also part of typical incubator services. The university, as a more specialised medium, can provide more specific training for start-ups, involving academics, experts, and they can acquire some of the entrepreneurial skills during their education. In our analysis of 35 university incubators, we found that they provide mentoring and training, 10 that they provide training only, 2 that they provide mentoring only and 1 that they contribute to networking. The next aspect is what other services they can provide to help entrepreneurs. In our table we have highlighted PR activities, contacting customers and investors, marketing, and tendering activities. In almost all of them, we found references to using a variety of methods to help companies to reach out to their environment, attend conferences and promote their reputation, thereby attracting customers and investors. On average, two of these services are provided (25 out of 48 here), only 5 mentioned one, and in the other cases, three (15) or four (3) were mentioned.

For incubators to be able to provide the activities mentioned so far to businesses and for entrepreneurs to be able to start their business, they need 
adequate capital, but their own resources are not always sufficient for this, so they need partner funding, which may even be beneficial for the partners in the future. In most cases (30 incubators), however, we found that a second party is needed at the start-up stage. For example, in the case of student start-ups, the students do not yet have sufficient capital to start their project, so a reliable partner is needed. This was found in 12 incubators. Only in some incubators (4) we found that the whole process was self-funded, and in some (2) the government contributed.

The last criterion on which we compared the university incubators was the organisational culture, for which we used Handy's [198G] culture typology as a basis. As a result, we found that the most typical (21) incubators were person-type, i.e., they were available to firms until they got over the initial difficulties. Next, a similarly high number (19) of incubators of the person-task type were found, i.e. in this case the university is more involved in the life of the company than in the person-only type, with more emphasis on project implementation, transfer and exploitation of expertise. There are also task-only (3), power-only (1), power-task (1) and role-task (3) types.

\section{G SUMMARY}

The most typical incubator has an average of three stakeholders/affected groups and a maximum of two primary targets. In terms of outcomes, two outcomes are expected by the majority, with the strategic focus dominated by a sector focus and the mixed focus incubator. In terms of interventions, the incubators studied prefer or feel the need for quantitative and mixed interventions, with management typically being mostly autonomous. Looking at the value creation of incubators, the majority preferred development activities, and a large majority provide space and facilities for incubated businesses. They seek to achieve professional development through mentoring and training and typically provide 2-3 services to the supported businesses. The capital used is typically provided by partners and the typical organisational culture is personal or person-to-person.

After enumerating the 12 most typical characteristics, we examined how many of the characteristics are found around the incubators studied, and how many incubators in total have each characteristic. Accordingly, the most common characteristics were the primary objective and intervention, occurring in $95.8 \%$ of incubators, affecting 4G incubators equally, while the least common was the expected outputs and the stakeholder aspect outcomes (22 and 21 incubators respectively). The average occurrence is around $72 \%$, this is most typical for the types of training (training + mentoring). 
The incubators studied were distributed according to their characteristics as follows. On average, incubators had the most frequent characteristic for nearly 9 aspects. The mode of the manifold is 9 , which means that the largest number of incubators (11) had 9 aspects among the most frequent. The least characteristic attribute of each criterion (5) was met in one case, the maximum 12 also in one case.

In the continuation of our research, as our research objectives have been achieved but further research questions have arisen, we would perhaps consider a direction to follow, comparing university incubators in geographical regions and highlighting regional differences (which may be due to the past or to intercultural differences between countries and regions). This would bring us closer to a model of a successful incubator that could be operational in Hungary. 


\section{BIBLIOGRAPHY}

Acs, Z., \& Plummer, L. (2005). Penetrating the "Knowledge Filter" in Regional Economies. The Annals of Regional Science, 439-45G.

Akhmat, G., Zaman, K., Tan, S., Javed, Y., \& Khan, M. (2014). Relationship between educational indicators and research outcomes in a panel of top twenty nations: Windows of opportunity. Journal of Informetrics, 349-3G1.

Al-Mubaraki, H., \& Busler, M. (2010). Business incubators models of the USA and UK: A SWOT analysis. World Journal of Entrepreneurship, Management and Sustainable Developement, 335-354.

Audretsch, D. (2014). From the entrepreneurial university to the university for the entrepreneurial society. The Journal of Technology Transfer, 313-321.

Bajmócy ,Z. (2005). "Vállalkozó egyetem" vállalkozásfejlesztési szemszögből. SZTE Gazdaságtudományi Kar Közleményei, 312-327.

Bajmócy, Z. (2004a). Az üzleti inkubáció szerepe a vállalkozásfejlesztésben. Közgazdasági Szemle, 1132-1150.

Bajmócy, Z. (2004b). Helyi társadalmi környezet a kisvállalkozások inkubációjában. SZTE Gazdaságtudományi Kar Közleményei, 229-242.

Bajmócy, Z. (200G). Egyetemi üzleti inkubáció lehetőségei elmaradott térségekben. Tér és Társadalom, 31-47.

Bajmócy, Z. (2011). Bevezetés a helyi gazdaság fejlesztésbe. Szeged: JATEPress.

Bajmócy, Z., Braxmair, Z., Imreh, S., \& Vilmányi , M. (2010). Az egyetemek lehetséges szerepe az új tudás-intenzív vállalkozások indításának ösztönzésében. Szeged: Szegedi Tudományegyetem.

Barbero, J., Casillas, J., Wright, M., \& Garcia , A. (2014). Do different types of incubators produce different types of innovations? Journal of Technology Transfer, 151-1G8.

Buzás , N., Kállay, L., \& Lengyel, I. (2003). Kis- és középvállalkozások a változó gazdaságban. Szeged.

Buzás, N. (2003). Organizational Elements of Knowledge Transfer in Hungary: Towards a Functional System of Innovation. Knowledge Transfer, Small and Mediunz-Sízed Enterprises, and Regional Development in Hungary, 32-4G.

Cantillon, R. (1755). Essai sur la nature du commerce en général. Paris: Marquis de Mirabeau.

Carayannis, E., \& von Zedtwitz, M. (2005). Architecting gloCal (global-local), realvirtual incubator networks (G-RVINs) as catalysts and accelerators of entrepreneurship in transitioning and developing economies:lessons learned and best practices from current development and business incubation. Technovation, 95-110. 
Chandra, A., Alejandra, M., \& Silva, M. (2012). Business Incubation in Chile: Development, Financing and Financial Services. Jounal of Technology Management \& Innovation, 1-13.

Clarysse, B., Wright, M., Lockett, A., Van de Velde, E., \& Vohora, A. (2005). Spinning out new ventures: a typology of incubation strategies from European research institutions. Research Policy(2), 183-21G.

Commision, E. (2003). Green Paper-Entrepreneurship in Europe. Brussels: Commission of the European Communities.

Dahms, S., \& Kingkaew, S. (201G). University Business Incubators: an institutional demand side perspective on Value Adding Features. Entrepreneurial Business and Economics Review.

Dániel , Z. A. (201G). Eszközvásárlásra kapott Uniós támogatások hatása a hazai kkv-k hozzáadott értékének változására és konvergencia folyamataikra, a 2007-2013-as tervezési időszakban. Veszprém: doktori értekezés.

Dee, N.-J., Livesey, F., Gill, D., \& Minshall, T. (2011). Incubation for growth: A review of the impact of business incubation on new ventures with high growth potential. London.

Drucker, P. (1993). Innováció a vállalkozások elméletében és a gyakorlatban. Budapest: Park Kiadó.

Erdős , K. (2019). Egyetemi vállalkozások Magyarországon- újragondolva? Közgazdasági Szemle, 305-329.

Ermakov, A. (201G). From the classical to the perfect university: Business incubator as driver of universities'innovation policy.

Etzkowitz, H. (1983). Entrepreneurial Scientists and Entrepreneurial Universities in American Academic Science. Minerva, 1-21.

Etzkowitz, H., Webster, A., Gebhardt, C., \& Terra, B. (2000). The future of the university, the university of the future: evolution of ivory tower to entrepreneurial paradigm. Research Policy, 29(2), 313-330.

European Commission . (2002). Benchmarking of Business Incubators. Luxembourg.

Feketéné Czakó, K. (2017). Vállalkozásfejlesztés és a területi tőke relációja- $A$ felsőoktatási intézmények szerepe. Győr.

Filion, L. (2011). Defining the entrepreneur. In L.-P. Dana (Ed.), World Ecyclopedia of Entrepreneurship (pp. 41-45). Cheltenham, UK: Edward Elgar.

Fülöp, G. (2004). Kisvállalati gazdálkodás. Budapesti Közgazdaságtudományi és Államigazgatási Egyetem Aula Kiadó.

Gazdig, G. (2009). A spin-off cégekről általában. Szolnok: Repüléstudományi konferencia különszáma.

Goldstein, H. (2010). The 'entrepreneurial turn' and regional economic development mission of universities. Annuals of Regional Science, 44, 83109. 
Grimaldi, R., \& Grandi, A. (2005). Business incubators and new venture creation: an assessment of incubating models. Technovation, 111-121.

Hackett, S., \& Dilts, D. (2004). A Real Options-Driven Theory of Business Incubation. The Journal of Technology Transfer, 41-54.

Handy, C. (198G). Szervezetek irányítása a változó világban. Budapest: Mezőgazdasági Kiadó.

Hashmi, A., \& Shah, A. (2013). Establishing National Science and Technology Park in Pakistan. World Technopolis Review, 2G4-275.

Hausberg , J., \& Korreck, S. (2018). Business incubators and accelerators: a cocitation analysis-based, systematic literature review. The Journal of Technology Transfer, 1-2G.

Hisrich, R., \& Peters, M. (1991). Vállalkozás- Új vállalkozás indítása, fejlesztése és működtetése. Budapest: Akadémiai Kiadó.

Imreh , S. (2005). Vállalkozásfejlesztés, mint a kis-és középvállalkozások hálózatosodásának ösztönzése. Szeged: doktori értekezés.

Jamil, F., Ismail, K., \& Mahmood, N. (2015). A Review of Commercialization Tools: University Incubators and Technology Parks. Malaysia: International Journal of Economics and Financial Issues.

Jamil, F., Ismail, K., \& Mahmood, N. (2015). A Review of Commercialization Tools: University Incubators and Technology Parks. International Journal of Economics and Financial Issues, 223-228.

Kleinheincz, F. (2002). Spin-off vállalkozások, avagy : barátkozzunk egy új megnevezéssel. Ipari szemle.

Kowang , O., Yee, T., Long, C., Rasli, A., \& Fairul, A. (2013). Technology Management: Developing an Innovation Model for Research Universities in Malaysia. Advanced Materials Research, 549-553.

Lalkaka, R. (1997). Lessons from International Experience for the Promotion of Business Incubation Systems in Emerging Economies (3 ed.). UNIDO Small and Medium Entreprises Programme Paper.

Lasrado, V., Sivo, S., Ford, C., O'Neal, T., \& Garibay, I. (201G). Do graduated university incubator firms benefit from their relationship with university incubators? Technol Transf, 205-219.

Lengyel, I. (2002). A regionális gazdaság- és vállalkozásfejlesztés alapvető szempontjai. Szeged: JATEPress.

Lewis , D., Harper-Anderson, E., \& Molnar, L. (2011). Incubating success: Incubation best pratices that lead to successful new ventures. Ann Arbor Michigan: University of Michigan.

Lewis, D. (2001). Does Technology Incubation Work? A Critical Review. Reviews of Economic Development Literature and Practice. U.S.: Economic Development Administration. 
Makra, Z. (2013). Az egyetemi spin-off vállalkozások jellegzetességei és alapításának folyamata a nemzetközi szakirodalom tükrében. (A. Inzelt, \& Z. Bajmócy, Eds.) Innovációs rendszerek. Szereplők, kapcsolatok és intézmények., 57-70.

Malecki, E. (1997). Technology and Economic Development: The dynamics of local, regional and national competitiveness. Edinburgh: Longman.

Malizia, E., Feser, E., Renski, H., \& Drucker, J. (1997). Understanding Local Economic Development. New Brunswick (NJ): Rutgers.

Marshall, A. (1920). Principles of Economics: An introductory volume. London,U.K.: Macmillan and Co.

Nicholls-Nixon, C., Valliere, D., \& Hassannezhad, Z. (2020). A Typology of University Business Incubators: Implications for Research and Practise. Toronto, Canada: Ted Rogers School of Management, Ryerson University. Pawlowski, K. (2009). The 'fourth generation university' as a creator of the local and regional development. Higher Education in Europe, 1, 51-G4.

Pirnay, F., Surlemont, B., \& Nlemvo, F. (2003). Toward a Typology of University Spin-offs. Small Business Economics, 355-3G9.

Redondo, M., \& Camarero, C. (2018). Social Capital in University Business Incubators: dimensions, antecedents and outcomes. International Entrepreneurship and Management Journal.

Roseira, C., Ramos, C., Maia, F., \& Henneberg, S. (2014). Understanding Incubator Value A Network Approach to University Incubators. FEP Working Papers.

Salem, M. (2014). The Role Of Business Incubators In The Economic Development Of Saudi Arabia. International Business and Economics Research Journal, 853-8G0.

Schillaci, C., Romano, M., \& Longo, M. (2011). Academic Entrepreneurship, University Incubator and Corporate Governance.

Schumpeter, J. A. (1980a). Az innováció. Budapest: Közgazdasági és Jogi Könyvkiadó. 237.

Schumpeter, J. A. (1980b). A gazdaság fejlödésének elmélete. Budapest: Közgazdasági és Jogi Könyvkiadó.

Soetanto, D., \& van Geenhuizen, M. (200G). Determinants of University Spin-offs' Growth: Do Socioeconomic Networks and Support Matter? Volos: Paper presented at the 4Gth Congress of the European Regional Science Association.

Somsuk, N., Laosirihongthong, T., \& McLean, M. (2012). Strategic management of university business incubators (UBIs): Resource-based view (RBV) theory. Industrial Management \& Data Systems, 245-2G7.

Somsuk, N., Wonglimpiyarat, J., \& Laosirihongthong, T. (2012). Technology Business Incubators and Industrial Development: Resource-Based View. Industrial Management \& Data Systems, 245-2G7. 
Spinelli, S, \& Timmons, J. A. (2003). New Venture Creation (Gth International Edition). New York.: McGraw-Hill/Irwin Publishers.

Stal, E., Andreassi, T., \& Fujino, A. (201G). The role of university incubators in stimulating academic entrepreneurship. Sao Paulo,Brasil.

Studdard, N. (200G). The effectiveness of entrepreneurial firm's knowledge acquisition from a business incubator. International Entrepreneurship Management Journal, 211-225.

Szerb, L. (2004). A vállalkozás és vállalkozói aktivitás mérése. Statisztikai Szemle, 545-5GG.

Szirmai, Á. (2005). The Dynamics of Socio-Economic Development. Cambridge: Cambridge University Press.

Tamásy, C. (2007). Rethinking Technology-Oriented Business Incubators: Developing a Robust Policy Instrument for Entrepreneurship , Innovation and Regional Development? . Growth and Change, 4G0-473.

Theodorakopoulos, N., K. Kakabadse, N., \& McGowan, C. (2014). What matters in business incubation? A literature review and a suggestion for situated theorising. Journal of Small Business and Enterprise Development, G02G22.

Tijssen, R., Lamers, W., \& Yegros, A. (2017). UK universities interacting with industry: patterns of research collaboration and inter-sectoral mobility of academic researchers. Working paper, 35.

Todorovic, Z., \& Suntornpithug, N. (2008). "The Multi-Dimensional Nature of University Incubators: Capability/Resource Emphasis Phases". Journal of Enterprising Culture, 385-410.

Vecsenyi, J. (2009). Kisvállalkozások indítása és müködtetése. Perfekt Gazdasági Tanácsadó, Oktató és Kiadó Zrt.

Wanklin, T. (2002). Understanding business incubation. UK: Nature Publishing Group.

Wann, J.-W., Lu, T.-J., Lozada , I., \& Cangahuala, G. (2017). University-based incubators' performance evaluation: a benchmarking approach. Benchmarking: An International Journal.

Westhead, P., Ucbasaran, D., \& Wright, M. (2005). Decisions, actions, and performance: Do novice, serial, and portfolio entrepreneurs differ? Journal of Small Business Management, 393-417.

Wissema, J. (2009). Towards the Third Generation University.Managing the university in transition. Cheltenham: Edward Elgar.

Wonglimpiyarat, J. (201G). The innovation incubator, university business incubator and technology transfer strategy: The case of Thailand. Technology in Society, 18-27. 

Incubators in the study sample

1. 3M BIC, University of Huddersfield, Egyesült Királyság https://3mbic.com/about/

2. AU Entrepreneurship Incubator, American University, Egyesült Államok https://www.american.edu/kogod/research/innovation/incubator-about.cfm

3. Austin Technology Incubator, University of Texas at Austin, Egyesült Államok https://ati.utexas.edu/about/

4. Bahrein University Business Incubation Center, University of Bahrain, Bahrein http://www.uob.edu.bh/en/index.php/administration/centers/businessincubators

5. BME Z10 Inkubátor, Budapesti Műszaki és Gazdaságtudományi Egyetem, Magyarország https://www.bme.hu/hirek/20200812/Igy szerezhetsz 15 millio forintot str atupod elinditasahoz a Muegyetemen

G. Brenau University Business Incubation, University of Brenau, Egyesült Államok https://www.brenau.edu/incubator/

7. Business Incubation and Growth Center (BIG Center), Northeastern Illinois University, Egyesült Államok https://www.neiu.edu/academics/college-ofbusiness-and-management/business-innovation-growth-center

8. Business Incubation Centre Southend, University of Essex, Anglia https://www.essex.ac.uk/business/business-incubation-centre-southend

9. C4DLab, University of Nairobi, Kenya https://c4dlab.ac.ke/incubation/

10.C-BRIDGE, Savitribai Phule Pune University, India http://iil.unipune.ac.in/incubatee.aspx

11. Centre for Entrepreneurship, University of Toronto, Kanada https://www.entrepreneurship.artsci.utoronto.ca/programs/incubator

12. Charles Sturt University Innovation Hub, Charles Sturt University, Ausztrália https://research.csu.edu.au/engage-with-us/incubators/agritech-incubator

13. Darwin Innovation Hub, Charles Darwin University, Ausztrália https://darwininnovationhub.com.au/

14. Division of University Corporate Relations, University of Tokyo, Japán https://www.ducr.u-tokyo.ac.jp/en/activity/venture/incubation/index.html

15. DMZ Incubator, Ryerson University, Kanada https://dmz.ryerson.ca/incubator/\#

1G. EagleLabs, Cranfield University, Anglia https://labs.uk.barclays/locations/cranfield

17. EIGERlab, Northern Illinois University, Egyesült Államok https://www.eigerlab.org/about-us/

18. EnterpriseWorks, University of Illinois Urbana Champaign, Egyesült Államok 
https://researchpark.illinois.edu/locate-here/enterpriseworks-incubator/

19. Francis Marion University Business Incubator, Francis Marion University, Dél-Karolina https://www.fmarion.edu/kelleycenter/incubation/

20. GU Ventures, University of Gothenburg, Svédország https://www.guventures.com/incubator

21. Helix 51 Incubator, Rosalind Franklin University, Egyesült Államok https://www.rosalindfranklin.edu/research/innovation-and-research-park/

22. Hertfordshire UniversityBusiness Incubation, University of Hertfordshire, Anglia https://www.herts.ac.uk/business/develop-your-business/businessincubation

23. IgniteLab, Loyola University, Egyesült Államok https://www.ignitelab.org/about

24. Incubate, University of Sydney, Ausztrália https://incubate.org.au/

25. Innovate Spriengfield, University of Illinos Springfield, Egyesült Államok https://www.innovatespringfield.org/

2G. IPN Incubator, University of Coimbra, Portugália https://www.ipn.pt/incubadora

27. Kyambogo University Incubation Center, University of Kyambogo, Uganda https://kyu.ac.ug/business-incubation-center-bic/

28. Luxembourg University Incubator, University of Luxembourg, Luxemburg https://wwwen.uni.lu/studies/incubator and entrepreneurship programme/ incubator

29. Lüneburg Innivation Incubator, Leuphana University, Németország https://www.leuphana.de/en/partners/innovation-incubator-lueneburg.html

30. Macquarie University Incubator, University of Macquarie, Ausztrália https://www.mq.edu.au/about/about-the-university/offices-andunits/macquarie-university-incubator/about

31. Maejo University Business Incubator, Maejo University, Thaiföld http://www.global.mju.ac.th/content.aspx?id=18

32. Maseno University Business Incubation, University of Maseno, Kenya https://www.maseno.ac.ke/index/index.php?option=com content\&view=artic le\&id=444:maseno-university-business-incubator-mubi\&catid=82:research

33. NTU Enterprise, Nottingham Trent University, Egyesült Királyság https://www.ntu.ac.uk/ntu-enterprise

34. Peoria NEXT Innovation Center, Bradley University, Egyesült Államok https://www.bradley.edu/sites/pnic/aboutus

35. Polsky Center, University of Chicago, Egyesült Államok https://polsky.uchicago.edu/

3G. Pretoria Incubation Process, University of Pretoria, Dél-afrikai Köztársaság https://www.up.ac.za/up-business-incubator

37. Qatar University Business Incubator, University of Qatar, Katar 
http://www.qu.edu.qa/business/entrepreneurship-center/business-incubator

38. Rice Alliance, Rice University, Egyesült Államok https://alliance.rice.edu/about

39. Sharda University Business Incubation Centre, University of Sharda, India https://www.sharda.ac.in/academics/business-incubation-centre

40. Small Business Incubator, Southern Illinois University, Egyesült Államok https://www.brenau.edu/incubator/

41. Startup Incubator, Oxford University, Egyesült Királyság https://innovation.ox.ac.uk/startupincubator/

42. Strathclyde University Incubator, University of Strathclyde, Egyesült Királyság http://www.suilimited.com/

43. Student Innovation Incubator, University of South Florida, Egyesült Államok https://www.usf.edu/research-innovation/rf/usf-connect/sii/

44. The Garage, Nortwestern University, Egyesült Államok https://thegarage.northwestern.edu/about/

45. TUM Entrepreneurship Center/ UnternehmerTUM, Technical University of Munich, Németország https://www.tum.de/en/innovation/entrepreneurship/about-us/ 4G.UCF Business Incubation Program, University of Central Florida, Egyesült Államok https://incubator.ucf.edu/overview/

47. University of Manchester Incubator Company Ltd., University of Manchester, Egyesült Királyság https://www.umic.co.uk/

48. University Technology Park, Illinois Institute of Technology, Egyesült Államok https://www.iit.edu/utp/about 